\title{
Pemetaan Prevalensi Balita Gizi Buruk di Provinsi Jawa Timur Tahun 2014 dengan Mixed Geographically Weighted Regression (MGWR)
}

\author{
Elvira Mustikawati Putri Hermanto \\ Universitas PGRI Adi Buana Surabaya \\ Jalan Dukuh Menanggal XII, Surabaya \\ e-mail: elvira.mustikawati@gmail.com
}

\begin{abstract}
ABSTRAK
Berdasarkan data Profil Kesehatan Indonesia, Pada tahun 2014, Provinsi Jawa Timur menempati urutan pertama kasus balita gizi buruk di Indonesia. Upaya-upaya telah dilakukan oleh pemerintah provinsi untuk perbaikan gizi secara intervensi spesifik (kesehatan) dan intervensi sensitive (non kesehatan). Penelitian ini dilakukan untuk mengetahui faktor-faktor yang berpengaruh terhadap persentase balita gizi buruk di masing-masing kabupaten/kota sekaligus faktor yang berpengaruh secara global di Provinsi Jawa Timur sebagai langkah untuk menekan kasus gizi buruk. Penelitian ini menggunakan metode Mixed Geographically Weighted Regression (MGWR). Berdasarkan hasil analisis dengan MGWR, diketahui variabel yang berpengaruh secara global adalah variabel X7 dan X10, sedangkan variabel yang berpengaruh secara local adalah variabel X1. Namun, berdasarkan uji kebaikan model dengan kriteria $\mathrm{R}^{2}$, diketahui bahwa model MGWR tidak lebih baik dibandingkan dengan model GWR. Nilai $\mathrm{R}^{2}$ MGWR adalah sebesar $53.60 \%$ sedangkan $\mathrm{R}^{2}$ GWR sebesar $61.53 \%$.
\end{abstract}

Kata kunci : Gizi Buruk, MGWR, GWR, $R^{2}$.

\begin{abstract}
Based on Indonesia Health Profile data, In 2014 East Java Province is in the first place of malnutrition in Indonesia. Efforts have been made by the provincial government as an effort to improve nutrition by specific interventions (health) and sensitive (non-health) interventions. As an effort to suppress malnutrition case in East Java Province, this research is done to know the factors that influence to percentage of malnourished children under five in each regency / city as well as globally influential factor in East Java Province. The method used is Mixed Geographically Weighted Regression (MGWR). Based on the results of analysis with MGWR, it is known that the variables that affect globally are variables X7 and X10, while the variables that affect locally is variable X1. However, based on model goodness test with R2 criteria, it is known that MGWR model is not better than GWR model. The value of $R^{2}$ of MGWR is $53.60 \%$ while $R^{2}$ of GWR is $61.53 \%$.
\end{abstract}

Keywords : Gizi Buruk, MGWR, GWR, $R^{2}$.

\section{PENDAHULUAN}

Indonesia telah menyepakati perjanjian Millenium Development Goals (MDGs) pada September tahun 2000. Salah satu kesepakatan MDGs yaitu memberantas kemiskinan dan kelaparan (UNDP, 2008). Sub target yang ingin dicapai dalam perjanjian MDGs salah satunya adalah mengurangi prevalensi balita dengan berat badan rendah, prevalensi balita gizi buruk, dan prevalensi balita gizi kurang (UNDP, 2008). Dengan mengikuti perjanjian MDGs, Indonesia harus mencapai prevalensi balita gizi buruk sebesar 3,6\% (UNDP, 2008). Secara Nasional, berdasarkan data Profil Kesehatan Indonesia
(Kemenkes, 2016), diketahui bahwa Provinsi Jawa Timur pada tahun 2015 berada di urutan pertama kasus balita gizi buruk. Terdapat 6.019 balita penderita gizi buruk di Jawa Timur dari 20.980 .298 balita di Indonesia (Kemenkes, 2016).

Menurut Direktur Gizi Masyarakat Kementerian Kesehatan, Ir. Doddy Izwardi (www.depkes.go.id), upaya perbaikan gizi terus dilakukan, baik intervensi spesifik (kesehatan) dan intervensi sensitif (non kesehatan). Upaya lain untuk mengurangi gizi buruk adalah mengetahui faktor yang berpengaruh terhadap kasus gizi buruk. Penelitian ini dilakukan untuk 
mengetahui faktor-faktor yang diduga mempengaruhi kasus balita gizi buruk di kabupaten/kota di Provinsi Jawa Timur dengan menggunakan metode Mixed Geographically Weighted Regression (MGWR) dengan mempertimbangkan aspek lokasi.

MGWR (Brunsdon et al, 1999) merupakan pengembangkan dari analisis regresi berbasis lokasi, Geographically Weighted Regression (Brunsdon et al, 1996). Dengan menggunakan metode MGWR, faktorfaktor yang ada dapat berpengaruh secara global di seluruh lokasi dan berpengaruh secara local di lokasi tertentu.

Berdasarkan hasil penelitian oleh Lestrina, (2009) diketahui bahwa faktor-faktor penyebab gizi buruk dapat berbeda antara satu wilayah dengan wilayah lainnnya, bahkan dapat berbeda antar kelompok masyarakat. Hal tersebut dapat disebabkan oleh adanya perbedaan karakteristik geografis, yang berkaitan dengan kemudahan akses sarana dan fasilitas di lokasi tertentu sehingga jumlah kasus gizi buruk di wilayah tersebut lebih rendah daripada wilayah lainnya.

Ayunin (2010) menyatakan terdapat variasi secara spasial atau variasi secara wilayah pada persebaran kejadian gizi buruk di Kabupaten Ngawi. Lestari (2012) melakukan penelitian dengan metode Geographically Weighted Regression (GWR) dengan studi kasus balita gizi buruk di Provinsi Jawa Timur. Berdasarkan penelitian tersebut diketahui bahwa terdapat tiga variabel mempengaruhi gizi buruk di Jawa Timur yaitu, pemeriksaan neonatus (KN1), pemeriksaan kehamilan, dan pelayanan imunisasi.

Hermanto (2013) meneliti faktor-faktor yang mempengaruhi prevalensi balita gizi buruk di Kabupaten Bojonegoro dengan menggunakan MGWR. Penelitian tersebut menghasilkan faktor-faktor yang berpengaruh di Kecamatan Bubulan adalah bayi yang mendapat ASI eksklusif, persalinan ditolong tenaga kesehatan, dan rumah tangga dengan air bersih. Sedangkan faktor bayi yang mendapat ASI eksklusif dan ibu hamil yang mendapat tablet Fe adalah yang berpengaruh terhadap prevalensi balita gizi buruk di Kecamatan Padangan.

\section{METODE PENELITIAN}

\subsection{Sumber Data}

Data diperoleh dari publikasi "Profil Kesehatan Provinsi Jawa Timur” (Dinkes Jatim, 2015). Unit observasi dalam penelitian ini adalah kabupaten/kota yang ada di Provinsi Jawa Timur. Variabel-variabel yang digunakan adalah Prevalensi balita gizi buruk (Y), Bayi mendapat ASI eksklusif (X1), Balita mendapat vitamin A (X2), Ibu hamil mendapat tablet Fe (X3), Kunjungan neonatus lengkap (X4), Pemeriksaan bayi menimal 8 kali (X5), Balita mendapat pelayanan kesehatan (X6),
Pemeriksaan ibu hamil (X7), Rumah tangga dengan air bersih (X8), Rumah tangga berperilaku hidup sehat (X9), Posyandu aktif (X10).

\subsection{Metode Analisis Data}

Langkah-langkah analisis data pada penelitian ini adalah sebagai berikut.

1. Mendeskripsikan seluruh variabel dan membuat peta tematik.

2. Melakukan pemodelan status balita gizi buruk dengan faktor-faktor yang diduga mempengaruhinya di Provinsi Jawa Timur dengan OLS.

3. Menganalisis model GWR

a. Menghitung jarak Eucliden $\left(d_{i j}\right)$ antar lokasi ke- $i$ pada koordinat $\left(u_{i}, v_{i}\right)$ terhadap lokasi ke-j pada koordinat $\left(u_{j}, v_{j}\right)$.

$$
d_{i j}=\sqrt{\left(u_{i}-u_{j}\right)^{2}+\left(v_{i}-v_{j}\right)^{2}}
$$

b. Menghitung bandwith optimum berdasarkan metode $\mathrm{CV}$.

c. Membuat matriks pembobot berdasarkan hasil (b).

d. Mengestimasi parameter model GWR.

e. Menghitung goodness of fit model GWR

f. Melakukan uji parsial parameter GWR.

4. Menganalisis model MGWR.

a. Menentukan variabel global dan variabel lokal berdasarkan hasil pengujian secara parsial model GWR.

b. Mengestimasi parameter model MGWR.

c. Menguji kesesuaian model MGWR.

d. Menguji secara serentak parameter variabel prediktor global dan lokal.

e. Menguji secara parsial parameter variabel prediktor global dan lokal.

5. Membandingkan model regresi GWR dan MGWR berdasarkan nilai $\mathrm{R}^{2}$.

\section{HASIL DAN PEMBAHASAN}

3.1 Deskripsi Prevalensi Balita Gizi Buruk dan Faktor yang Mempengaruhinya

Rata-rata persentase balita gizi buruk (y) di Provinsi Jawa Timur adalah $0.014 \%$. Kabupaten Lumajang merupakan kabupaten dengan persentase balita gizi buruk tertinggi, yaitu sebesar 0.059\%. Kabupaten Jombong dan Kabupaten Sidoarjo merupakan dua kabupaten dengan persentase balita gizi buruk terendah. Gambar 1. merupakan peta persebaran balita gizi buruk di Provinsi Jawa Timur. 


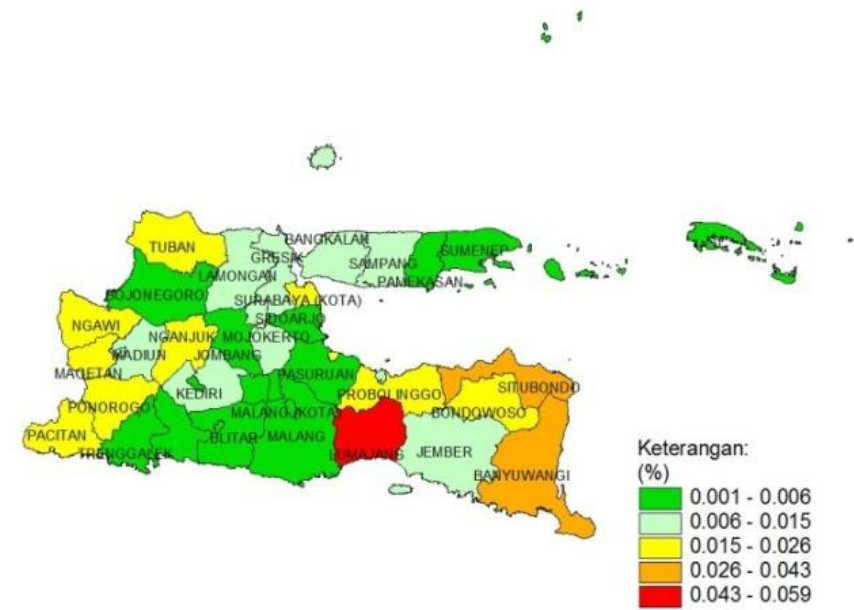

Gambar 1. Persebaran Persentase Balita Gizi Buruk di Kabupaten/Kota di Provinsi Jawa Timur Tahun 2014

Rata-rata persentase pemberian ASI eksklusif (X1) di Provinsi Jawa Timur adalah sebesar $72.75 \%$ dan variasi nilainya antar kabupaten/kota sebesar $78.31 \%$. Pemberian ASI eksklusif terendah berada di Kabupaten Pamekasan dengan persentase sebesar $51.70 \%$. Sedangkan persentase pemberian ASI Eksklusif tertinggi berada di Kabupaten Bojonegoro.

Rata-rata persentase kunjungan neonatus lengkap (X4) di Provinsi Jawa Timur adalah sebesar 98.28\% dengan keragaman antar kabupaten/kota sebesar 6.28\%. Kabupaten Pacitan merupakan kabupaten dengan persentase kunjungan neonatus lengkap terendah, yaitu sebesar $90.10 \%$. Terdapat 20 kabupaten/kota di Jawa Timur dengan tingkat kunjungan neonatus lengkap sebesar $100 \%$, beberapa diantaranya adalah Kabupaten Ngawi dank Kota Kediri.

Rata-rata persentase pemeriksaan ibu hamil (X7) di Provinsi Jawa Timur sebesar 88.32\% dengan keragaman antar kabupaten/kota sebesar 32.46\%. Persentase pemeriksaan ibu hamil di Kabupaten Jember sebesar 75.44\% dan menempati urutan terendah. Sedangkan Kota Madiun menempati urutan teratas persentase pemeriksaan ibu hamil dengan persentase $98.23 \%$.

\subsection{Pemodelan dengan Regresi Linier}

Penentuan model terbaik dilakukan dengan regresi stepwise yang menghasilkan lima variabel prediktor yang berpengaruh signifikan terhadap persentase balita gizi buruk di Provinsi Jawa Timur, yaitu X1, X4, X7, X9, dan X10. Regresi stepwise menghasilkan $\mathrm{R}^{2}$ sebesar $55.15 \%$ (Tabel 1.).

Sehingga model yang terbentuk dengan regresi stepwise adalah sebagai berikut (persamaan 1)

$$
\hat{Y}=4.49-0.62 X 1+1.58 X 4-2.52 X 7+
$$
$+0.89 X 9-0.98 \times 10$
Tabel 1. Hasil Pengujian Parameter Model Dengan Regresi Stepwise

\begin{tabular}{lrcr}
\hline $\begin{array}{c}\text { Estimasi } \\
\text { Parameter }\end{array}$ & $\begin{array}{c}\text { Nilai } \\
\text { Estimasi }\end{array}$ & \multicolumn{1}{c}{$t$} & $\begin{array}{c}\text { Nilai } \\
\text { Signifikansi }\end{array}$ \\
\hline$\widehat{\beta}_{0}$ & 4.487 & 12.790 & ${ }^{*} 0.000$ \\
$\widehat{\beta}_{1}$ & -0.617 & -1.540 & ${ }^{*} 0.133$ \\
$\widehat{\beta}_{4}$ & 1.581 & 3.470 & ${ }^{*} 0.002$ \\
$\widehat{\beta}_{7}$ & -2.524 & -5.400 & ${ }^{*} 0.000$ \\
$\widehat{\beta}_{9}$ & 0.896 & 1.960 & ${ }^{*} 0.059$ \\
$\widehat{\beta}_{10}$ & -0.982 & -2.580 & ${ }^{*} 0.015$ \\
\hline \hline
\end{tabular}

Keterangan: ${ }^{*}$ Signifikan pada $\alpha=15 \%$

\subsection{Uji Efek Spasial}

Berdasarkan hasil pengujian dengan uji Moran's I dan Uji Breusch-Pagan, diketahui bahwa terdapat aspek spasial heterogeniti. Hal tersebut didasari oleh nilai signifikansi hasil uji Breusch-Pagan test lebih kecil dari toleransi kesalahan 10\% (Tabel 2.). Pendekatan yang dilakukan adalah pendekatan berbasis titik. Oleh karena itu metode GWR dan MGWR dapat dilakukan untuk memodelkan prevalensi balita gizi buruk di Provinsi Jawa Timur. 
Tabel 2. Uji Efek Spasial dengan Uji Moran's I dan Breusch-Pagan

\begin{tabular}{lr}
\hline Pengujian & \multicolumn{1}{c}{$\begin{array}{c}\text { Nilai } \\
\text { Signifikansi }\end{array}$} \\
\hline Breusch-Pagan & ${ }^{*} 0.001858$ \\
Moran's I & 0.2175468 \\
\hline
\end{tabular}

Keterangan: ${ }^{*}$ Signifikan pada $\alpha=10 \%$

\subsection{Model GWR}

Pembobot GWR yang dicobakan adalah Gaussian, Tricube, dan Bisquare yang dibedakan berdasarkan fiz dan adaptif. Berdasarkan hasil perhitungan, Adaptif Bisquare merupakan pembobot terbaik untuk melakukan memodelkan kasus dengan GWR, karena menghasilkan $\mathrm{R}^{2}$ yang optimal (Tabel 3).

Tabel 3. Pembobot Terbaik Model GWR berdasarkan Kriteria $\mathrm{R}^{2}$

\begin{tabular}{llr}
\hline $\mathrm{R}^{2}$ & Fix & Adaptive \\
\hline Gaussian & $57.58 \%$ & $56.77 \%$ \\
Tricube & $58.29 \%$ & $60.11 \%$ \\
Bisquare & $58.53 \%$ & $* 61.53 \%$ \\
\hline
\end{tabular}

Keterangan: ${ }^{*}$ Pembobot terbaik
Berdasarkan hasil pengujian kesesuaian model GWR diperoleh nilai $F$ sebesar 1.074 lebih kecil dari nilai $\mathrm{F}_{0.9 ; 30.67}=3.81(\alpha=10 \%)$. Hal tersebut menunjukkan $\mathrm{H} 0$ ditolak. Dengan kata lain, terdapat perbedaan antara model regresi OLS dan model GWR sehingga faktor lokasi berpengaruh terhadap prevalensi balita gizi buruk. Oleh karena itu, model GWR layak untuk menggambarkan prevalensi balita gizi buruk yang terjadi di Provinsi Jawa Timur.

Hasil uji parameter parsial dilakukan untuk mengetahui variabel prediktor yang berpengaruh di masing-masing kecamatan. Model GWR untuk Kota Surabaya ditunjukkan oleh persamaan 2.

$$
\begin{aligned}
\hat{Y} & =4.639-0.766 X 1+1.351 X 4-2.388 X 7+ \\
& +0.836 X 9-1.065 X 10
\end{aligned}
$$

Sedangkan model GWR untuk Kabupaten Sampang ditunjukkan oleh persamaan 3 .

$$
\hat{Y}=4.587+1.100 X 4-2.291 X 7-1.026 X 10
$$

Gambar 2. menunjukkan persebaran variabel prediktor yang berpengaruh di tiap kabupaten/kota di Provinsi Jawa Timur.

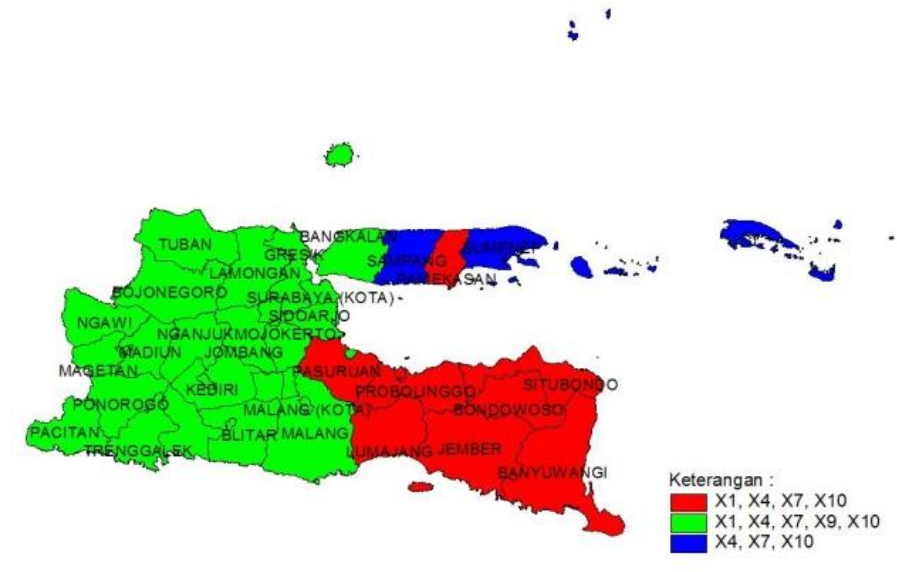

Gambar 2. Persebaran Variabel Prediktor yang Berpengaruh dengan GWR di kabupaten/kota di Provinsi Jawa Timur Tahun 2014

\subsection{Model MGWR}

Berdasarkan Tabel 4, F1 merupakan hasil pengujian kesesuaian model MGWR menunjukkan bahwa $\mathrm{H}_{0}$ ditolak karena nilai signifikansi $\mathrm{F}$ lebih kecil dari tingkat kesalahan sebesar 10\%. Oleh karena itu model MGWR dan model regresi OLS berbeda signifikan. Variabel X7 dan X10 pada model GWR berpengaruh di semua kabupaten/kota sehingga variabel tersebut dianggap sebagai variabel yang berpengaruh secara global di

\begin{tabular}{|c|c|c|}
\hline Uji & $\begin{array}{c}\text { F- } \\
\text { hitung }\end{array}$ & $\begin{array}{c}\text { Nilai } \\
\text { Signifikansi }\end{array}$ \\
\hline$F(1)$ & 1.14 & $3.54 \times 10^{-1}$ \\
\hline$F(2)$ & 16.09 & $4.40 \times 10^{-12}$ \\
\hline$F(3)$ & 24.56 & $2.22 \times 10^{-16}$ \\
\hline
\end{tabular}
Tabel 4. Ringkasan Pengujian Model MGWR Provinsi Jawa Timur. 
Hasil uji serentak variabel global yang diduga mempengaruhi variabel respon $\mathrm{Y}$ ditunjukkan oleh $\mathrm{F}(2)$ pada Tabel 4. Berdasarkan hasil pengujian $\mathrm{F}(2)$ diperoleh nilai signifikansi sebesar $4.40 \times 10^{-12}$ yang lebih kecil dari tingkat toleransi $10 \%$ sehingga $\mathrm{H} 0$ ditolak. Kesimpulan tersebut didukung oleh hasil yang ditunjukkan oleh model GWR, yaitu variabel X7 dan X10 yang berpengaruh di seluruh kabupaten/kota. Setelah melakukan pengujian serentak, kemudian dilakukan pengujian terhadap variabel prediktor yang bersifat global secara parsial. Nilai signifikansi hasil pengujian parsial prediktor global adalah sebesar 0.001 untuk X7 dan 0.003 untuk X10. Nilai tersebut lebih kecil dari batas toleransi kesalahan 10\%. Berdasarkan hasil tersebut disimpulkan bahwa baik secara serentak maupun parsial X7 dan X10 berpengaruh terhadap persentase balita gizi buruk di Provinsi Jawa Timur secara global.

Pengujian yang dilakukan selanjutnya adalah menguji variabel yang diduga berpengaruh lokal di tiap kabupaten/kota secara serentak, yaitu variabel X1, X4, dan $\mathrm{X} 9 . \mathrm{H}_{0}$ adalah tidak ada variabel yang diduga bersifat lokal berpengaruh terhadap variabel respon. Nilai signifikansi uji serentak untuk variabel lokal ditunjukkan $\mathrm{F}(3)$ dengan nilai sebesar $2.22 \times 10^{-16}$ lebih kecil dari $10 \%$, sehingga $\mathrm{H}_{0}$ ditolak atau ada variabel yang bersifat lokal berpengaruh terhadap respon $\mathrm{Y}$.

Model MGWR $(\alpha=10 \%)$ yang terbentuk untuk Kota Surabaya dinjukkan oleh persamaan 4.

$$
\hat{Y}=4.551-0.491 X 1-1.387 X 7-0.953 X 10
$$

Sedangkan model MGWR $(\alpha=10 \%)$ yang terbentuk untuk Kabupaten Sampang ditunjukkan oleh persamaan 5.

$$
\hat{Y}=4.408-0.399 X 1-1.387 \times 7-0.953 X 10
$$

Peta penyebaran variable yang bersifat lokal yang berpengaruh di tiap kabupaten/kota di Provinsi Jawa Timur ditunjukkan oleh Gambar 3.

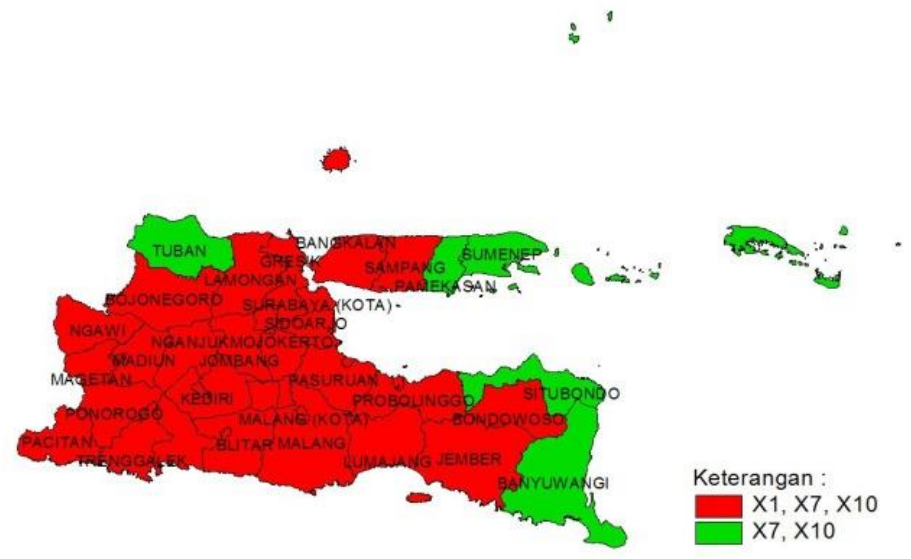

Gambar 3. Persebaran Variabel Prediktor yang Berpengaruh dengan MGWR di kabupaten/kota di Provinsi Jawa Timur Tahun 2014

3.6 Perbandingan Model OLS, GWR, dan MGWR Berdasarkan kriteria $\mathrm{R}^{2}$ diketahui bahwa model GWR adalah model yang paling tepat untuk memodelkan prevalensi gizi buruk di Provinsi Jawa Timur karena mempunyai nilai $\mathrm{R}^{2}$ terbesar (Tabel 5.).

Tabel 5. Pemilihan Model Terbaik dengan Kriteria $\mathrm{R}^{2}$

\begin{tabular}{lr}
\hline \multicolumn{1}{c}{ Model } & \multicolumn{1}{c}{$\mathrm{R}^{2}(\%)$} \\
\hline Global & 55.15 \\
GWR $^{*}$ & 61.53 \\
MGWR & 53.60 \\
\hline
\end{tabular}

\section{KESIMPULAN DAN SARAN}

Berdasarkan hasil analisis dengan metode MGWR, diketahui bahwa variabel X7 dan X10 berpengaruh signifikan terhadap persentase balita gizi buruk (Y) di seluruh kabupaten/kota di Provinsi Jawa Timur (berpengaruh secara global). Model MGWR di Kota Surabaya adalah

$$
\hat{Y}=4.551-0.491 X 1-1.387 X 7-0.953 X 10
$$

Akan tetapi, berdasarkan kriteria $\mathrm{R}^{2}$, model MGWR tidak lebih baik untuk menggambarkan persentase kejadian balita gizi buruk di Provinsi Jawa Timur dibandingkan dengan model GWR.

Model terbaik yang menggambarkan persentase kejadian balita gizi buruk adalah GWR karena nilai $\mathrm{R}^{2}$, yaitu sebesar $61.53 \%$. Model GWR pada Kecamatan Sampang adalah

$$
\hat{Y}=4.587+1.100 X 4-2.291 X 7-1.026 X 10
$$




\section{DAFTAR PUSTAKA}

Ayunin, Latifah. 2011. Pemodelan Balita Gizi Buruk di Kabupaten Ngawi dengan Geographically Weighted Regression. Tugas Akhir Jurusan Statistika FMIPA ITS, Surabaya.

Brunsdon, C., Fotheringham, A.S., and Charlton, M. 1996. Geographically Weighted Regression: A Method for Exploring Spatial Nonstationary. Geographical Analysis; Vol. 28: 281-298.

Brunsdon C, Fotheringham A S, Charlton M. 1999. "Some Notes on Parametric Significance tests for geographically weighted regression". Journal of Regional Science, vol. 39, hal. 497524.

[Dinkes Jatim] Dinas Kesehatan Provinsi Jawa Timur. 2015. Profil Kesehatan Provinsi Jawa Timur. Surabaya: Dinas Kesehatan Provinsi Jawa Timur.

Hermanto, E.M.P. 2013. Pemodelan dan Pemetaan Prevalensi Balita Gizi Buruk serta FaktorFaktor yang Mempengaruhinya di Kabupaten Bojonegoro dengan Pendekatan Mixed Geographically Weighted Regression. Tugas Akhir Jurusan Statistika FMIPA ITS, Surabaya.

Kementerian Kesehatan Republik Indonesia 22 Maret 2016. Diakses pada 20 Desember 2016. http://www.depkes.go.id/article/view/160322 00005/tahun-2015-pemantauan-status-gizidilakukan-di-seluruh-kabupaten-kota-diindonesia.html

[Kemenkes RI] Kementerian Kesehatan Republik Indonesia. 2016. Profil Kesehatan Indonesia. Jakarta: Kementerian Kesehatan Republik Indonesia.

Lestari, RL. 2012. Pemodelan Balita Gizi Buruk Di Provinsi Jawa Timur Dengan Pendekatan Geographically Weighted Regression. Tugas Akhir Jurusan Statistika FMIPA ITS, Surabaya.

Lestrina, D. 2009. Penanggulangan Gizi Buruk Di Wilayah Kerja Puskesmas Lubuk Pakam Kabupaten Deli Serdang. Tesis, Program Studi Ilmu Kesehatan Masyarakat Universitas Sumatera Utara, Medan.

[UNDP] United Nations Development Programme. 2008. Millennium Develompment Goals. Jakarta: UNDP. Diunduh pada 20 Desember 2016.

http://www.undp.org/content/dam/indonesia/d ocs/MDG/Let\%20Speak\%20Out\%20for $\% 20$

MDGs\%20-\%20ID.pdf 